counselling and were marginally worse than those of other psychiatric treatments. In some well designed controlled studies that focused on discrete disorders such as bulimia nervosa, however, outcomes were similar in patients treated with cognitive behavioural therapy or brief psychodynamic therapies. We remain relatively ignorant about how the brief psychotherapies work and how they can be best delivered. Certainly, the evidence is not available to allow purchasers to decide which brief therapies the health service should offer.

Purchasers must also be aware of the rapid spread of counselling services, which now dominate the mental health services provided in primary care. This growth has been seemingly unhampered by the absence of a satisfactory definition of what is on offer as well as a lack of controlled evaluations. A recent survey showed that a high proportion of counsellors lacked qualifications and were working without adequate supervision. ${ }^{14}$

A further challenge for those purchasing or providing psychotherapy services is to avoid limiting their vision to the traditional users of mental health services. It is well established that psychological disorders are common outside these settings. For example, health care economists at Kaiser Permanente wrote that, if unchecked, the unmet mental health needs of patients in general hospitals might bankrupt the American health care system. ${ }^{15}$ The general hospital is frequently referred to as "America's second mental health service." Somatisation disorders, chronic fatigue, myalgia, and irritable syndromes, as well as the psychological problems of physical illness, account for an immense burden of morbidity to sufferers and cost to the NHS. ${ }^{16}$ Yet these patients are frequently overlooked by the providers of acute medical care and remain invisible to the customary providers of mental health services. This is regrettable, as both behavioural and cognitive behavioural approaches are rapidly proving their effectiveness for these groups ${ }^{17}$ and, ironically, one of the most convincing demonstrations of the efficacy of dynamic psychotherapy took place in a general hospital. ${ }^{18}$

Some patients do not respond to the brief therapies or, owing to the long duration or severity of their disorders, are deemed unsuitable for these interventions. Psychotherapists may be the only clinicians who can help these difficult patients, but to continue to do so they must justify the cost of treatment, not only in terms of improved health of their patients but also in terms of decreased costs to the NHS. They must also overcome the problem of engaging certain reluctant client groups, such as young people and those of lower social class. ${ }^{19}$

The new marketplace will have important consequences for both providers and purchasers of psychotherapy services. Purchasers must now ensure the availability of the newer brief psychotherapies of proved value in neurotic disorders. They may also need to resist the demand for more counselling services until better evidence of efficacy and safety is available. Finally, they need to take the leading role in ensuring that access to psychotherapy moves beyond the traditional clients of mental health services.

TOM FAHY Lecturer

SIMON WESSELY Senior lecturer

Academic Department of Psychological Medicine,

King's College School of Medicine and Dentistry and Institute of Psychiatry,

London SE5 9RS

1 Marks I. Fears, phobias and rituals. New York: Oxford University Press, 1987.

2 Ginsberg G, Marks I. Costs and benefits of behavioural psychotherapy: a pilot study of neurotics treated by nurse therapists. Psychol Med 1977;7:685-700.

3 Marks I. Controlled trial

4 Beck AT, Hollon SD, Young JE, Bedrosian RC, Budenz D. Treatment of depression with cognitive therapy and amitriptyline. Arch Gen Psychiatry 1985;42:142-8.

5 Blackburn IM, Eunson KM, Bishop S. A two-year naturalistic follow-up of depressed patients treated with cognitive therapy, pharmacotherapy and a combination of both. $\mathcal{J}$ Affect Di 1986;10:67-75.

6 University of Leeds. The treatment of depression in primary care. Effective Health Care Bulletin No 51993: March.

7 Hawton K, Salkovskis P, Kirk J, Clark D. Cognitive behaviour therapy for psychiatric patients: a practical guide. Oxford: Oxford University Press, 1989.

8 Fairburn C, Jones R, Peveler R, Hope R, O'Connor M. Psychotherapy and bulimia nervosa: Longer-term effects of interpersonal psychotherapy, behavior therapy and cognitive behavio therapy. Arch Gen Psychiatry 1993;50:419-28.

9 Milton J. Presenting the case for psychoanalytic psychotherapy services. An annotated bibliography. Discussion document. London: Association for Psychoanalytic Psychotherapy in the NHS and Discussion document. Lo
Tavistock Clinic, 1992.

10 Clementel-Jones C, Malan D, Trauer T. A retrospective follow-up of 84 individual psychoanalytic psychotherapy. Outcome and predictive factors. British fournal of Psychotherapy 1990;6:363-74.

11 Andrews G. The essential psychotherapies. Br f Psychiatry 1993;162:447-51.

12 Andrews G, Hadzi-Pavlovic D. The work of Australian psychiatrists, circa 1986. Aust NZ Psychiatry 1988;22:153-65.

13 Crits-Christoph $P$. The efficacy of brief dynamic psychotherapy: a meta-analysis. Am $\mathcal{F}$ Psychiatry 1992;149:151-8.

14 Sibbald B, Addington-Hull J, Brennerman D, Freeling P. Counselling in English and Welsh general practices: their nature and distribution. BMF 1993;306:29-33.

15 Cummings N, VandenBos G. The twenty years Kaiser-Permanente experience with psychotherapy and medical utilization: implications for national health policy and national health insurance. Health Policy Quarterly 1981;1:159-75.

16 Fink P. Surgery and medical treatment in persistent somatizing patients. $f$ Psychosom Res 1992;36:439-47.

17 Sharpe $M$, Peveler $R$, Mayou $R$. The psychological treatment of patients with functional somatic symptoms: a practical guide. I Psychosom Res 1992;36:55-29.

symptoms: a practical guide. f Psychosom Res $1992 ; 36: 55-29$.
18 Guthrie E, Creed F, Dawson D, Tomenson B. A controlled trial of psychological treatment for the irritable bowel syndrome. Gastroenterology 1991;100:450-7.

19 Scott A, Freeman C. Edinburgh primary care depression study: treatment outcome, patient satisfaction and cost after 16 weeks. BMf 1992;304:883-7.

\title{
From specialist care to self directed treatment
}

\author{
Empower the patient and spare the clinician
}

We can no longer escape the conclusion that the number of patients who can be helped by treatment that depends on technology is limited by constraints on resources. This applies as much to psychological as to physical treatments. The specialist knowledge, skills, and time required for one to one psychotherapy, for example, are also limited resources. A possible way to resolve this dilemma may be for some patients to use self directed treatment manuals, thereby saving scarce resources for those who need them most. An additional benefit of this approach, in which skill is shared with the users of health care, is that it enables patients to become more actively involved in their own health care. ${ }^{1}$ Arguments that such methods increase users' mastery and self esteem make a virtue out of necessity. The important questions are whether self directed treatment works and for which conditions.

Despite the overwhelming number of books on health problems that have been written specifically for the public, relatively few actually teach users how to deal with their problems. Even fewer of these texts have been tested against other interventions. ${ }^{2}$

One approach of self directed treatment has been to educate people about harmful lifestyles and to teach them how to minimise the ensuing risk to health. Manuals to reduce smoking seem to be a weak intervention when used alone, ${ }^{3}$ unless motivation is increased. ${ }^{4}$ Pregnancy may provide such 
motivation. ${ }^{5}$ Alternatively, media publicity or telephone or group contact may provide enough added support. ${ }^{6-8}$ Likewise, the addition of minimal contact with a therapist seems to enhance the effectiveness of weight loss manuals, but competitive incentives are of particular benefit. ${ }^{9}$

Most intervention studies are short term, focusing on reducing symptoms. Other self direction manuals have broader aims. A "heart manual," for example, covered education, an exercise programme, stress management techniques, and the self treatment of common postoperative psychological problems. At one year follow up the people using the manual were significantly less psychologically disturbed, three times less likely to die, and significantly less likely to have another infarction over the next five years than those given only stress management training. ${ }^{10}$

Similar techniques have been used to treat emotional disorders such as depression, ${ }^{112}$ anxiety, ${ }^{1314}$ phobias, ${ }^{15-17}$ panics, ${ }^{18}$ and eating disorders. ${ }^{19}$ Patients report being as satisfied with this form of treatment as they are with conventional treatment with a therapist. ${ }^{20}$ The effects of self directed treatment seem to be long lasting, with improvements maintained for several years. ${ }^{12-18} 21$ Teaching the partners of psychiatric patients can also have benefits, increasing their understanding of the illness and strengthening core relationships. $^{22}$

What are the critical elements in successful self directed treatment? Simply giving general advice and information alone is insufficient, although it may lead the reader to seek help. There is plenty of evidence that self directed treatment manuals that teach users key techniques for overcoming problems give more successful results than simple education leaflets. ${ }^{1023}$ But the order of delivery of components may be important. For example, problem drinkers given strategies for self regulation first and then education had a significantly greater reduction of alcohol intake than a group who received these components in the reverse order. ${ }^{25}$ No differences have yet been found between competing therapeutic rationales such as behavioural and cognitive treatment. ${ }^{10}$

Self directed treatments thus seem to be effective in a variety of conditions. Most of the research so far has tested written materials. Computers have the potential to add "therapeutic interactions" which printed materials cannot, ${ }^{26}$ and television interventions may also have potential. Self directed interventions are attractive because they allow the possibility of many more patients being treated closer to home and because they allow patients to play an important part in their own treatment. These interventions are unlikely to do specialists out of a job; instead, integration of these approaches into practice will free clinicians' time and skill to focus on the problems of the more severely ill patients.

NICHOLAS TROOP

Doctoral student

JANET TREASURE

Senior lecturer

Psychiatry Department,

Institute of Psychiatry,

London SE5 8AF

ULRIKE SCHMIDT Consultant

Psychiatry Department,

St Mary's Hospital,

London W2 $1 \mathrm{NY}$

1 King's Fund Commission. London health care 2010: changing the future of services in the capital. London: King's Fund, 1992.

2 Turvey A. Treatment manuals. In: Watts FN, ed. New developments in clinical psychology. London British Psychological Society, 1985.

3 Glasgow RE, Rosen GM. Behavioural bibliotherapy: a review of self-help behaviour therapy manuals. Psychol Bull 1978;85:1-23.

4 Glynn T, Boyd G, Gruman J. Essential elements of self-help/minimal intervention strategies for smoking cessation. Health Educ $Q$ 1990;17:329-45.

5 Hjalmarson AI, Hahn L, Svanberg B. Stopping smoking in pregnancy: effect of a self-help manual in a controlled trial. Brf Obstet Gynaecol 1991;98:260-4.

6 Orleans CT, Schoenbach VJ, Wagner EH, Quade D, Salmon MA, Pearson DC, et al. Self-help quit smoking intervention: effects of self-help materials, social support instructions and telephone counselling. 7 Consult Clin Psychol 1991;59:439-48.

7 Ossip-Klein D, Gionano G, Megahed N, Black P, Emant S, Stiggins J, et al. Effects of a smokers' hot-line: results of a 10-county self-help trial. F Consult Clin Psychol 1991;59:325-32.

8 Gruder CL, Warnecke RB, Jason LA, Flay BR, Peterson P. A televised, self-help, cigarette smoking cessation intervention. Addictive Behaviours 1990;15:505-16.

$9 \mathrm{Klem}$ ML, Klesges R. Competition in a minimal-contact weight loss programme. $\mathcal{f}$ Consult Clin Psychol 1988;56:142-4.

10 Lewin B, Robertson I, Clay E, Irving J, Campbell M. Effects of self-help post-myocardial infarction rehabilitation on psychological adjustment and use of health services. Lancet 1992:339:1036-40.

11 Scogin F, Jamison C, Gochneaur K. Comparative efficacy of cognitive and behavioural bibliotherapy for mildly and moderately depressed older adults. I Consult Clin Psychol 1989;57:403-7.

12 Scogin F, Jamison C, Davis N. Two-year follow-up of bibliotherapy for depression in older adults. f Consult Clin Psychol 1990;58:665-7.

13 Donnan P, Hutchinson A, Paxton R, Grant B, Firth M. Self-help materials for anxiety: a randomized controlled trial in general practice. BrF Gen Pract 1990;40:498-501.

14 Sorby N, Reavley $W$, Huber J. Self-help programme for anxiety in general practice: controlled trial of an anxiety management booklet. Br J Gen Pract 1991;41:417-20.

15 Baker BL, Cohen DC, Saunders JT. Self-directed desensitization for acrophobia. Behav Res Ther 1973;11:79-89.

16 Rosen GM, Glasgow RE, Barrera M Jr. A controlled study to assess the clinical efficacy of totally self-administered systematic desensitization. F Consult Clin Psychol 1976;44:208-17.

17 Ghosh A, Marks IM, Carr A. Therapist contact and outcome of self-exposure treatment for phobias. Br f Psychiatry 1988;152:234-8.

18 McNamee G, O'Sullivan G, Lelliot P, Marks IM. Telephone-guided treatment for housebound agoraphobics with panic disorder: exposure vs relaxation. Behaviour Therapy 1989;20:491-7.

19 Schmidt U, Tiller J, Treasure J. Self-treatment of bulimia nervosa: a pilot study. Intermational foumal of Eating Disorders 1993;13(3):273-7.

20 Ghosh A Marks IM. Self-treatment of agoraphobia by exposure. Behaviour Therapy 1987;18:3-16.

21 O'Sullivan G, Marks IM. Long-term follow-up of phobics and obsessive compulsives. In: Noyes R, Roth M, Burrows G, eds. Handbook of anxiety. Amsterdam: Elsevier, 1991:87-108.

22 Van Gent EM, Zwart FM. Psychoeducation of partners of bipolar-manic patients. $f$ Affective Disord 1991;21:15-8.

23 Heather N, Robertson I, MacPherson B, Allsop S, Fulton A. Effectiveness of a controlled drinking self-help manual: one year follow up results. Br f Clin Psychol 1987;26:279-87.

24 Heather N, Kissoon-Singh J, Fenton GW. Assisted natural recovery from alcohol problems: effects of self-help manual with and without supplementary telephone contact. $\mathrm{Br} \mathcal{F}$ Addict 1990;85: $1177-85$.

25 Savage SA, Hollin CR, Hayward AJ. Self-help manuals for problem drinking: the relative effects of their educational and therapeutic components. Br f Clin Psychol 1990;20:373-82.

26 Taylor CB, Agras WS, Losch M, Bumett KF. Improving the effectiveness of computer-assisted weight loss. Behaviour Therapy 1991;22:229-36.

\section{Apheresis in the 1990s}

\section{Technological innovations are opening up new therapeutic vistas}

Apheresis is the removal of selected components from the blood by using cell separators. Medical technology has not yet, however, reached the future as envisaged by Professor Edwin J Cohn of Harvard Medical School in the late 1940s. This great pioneer protein fractionator believed that ultimately it should be possible to separate out all the formed elements of the blood immediately after its withdrawal from the donor. Forty years on this vision of the future has not yet been realised, but enormous progress has been made on both the cellular and humoral fronts.

Plasmapheresis was first used in 1914 in experiments on dogs. ${ }^{1}$ In 1944 Co Tui and his coworkers showed that frequent plasmapheresis of donors could meet the demand for plasma to cope with wartime emergencies. ${ }^{2}$ Plasmapheresis was first used therapeutically in 1952, when it was tried as a means of controlling hyperviscosity in multiple myeloma. ${ }^{3}$ Once Judith Pool had described cryoprecipitated factor VIII concentrate commercial companies were quick to seize the plasmapheresis initiative by introducing paid plasma donation as a means of obtaining large quantities of fresh frozen plasma for fractionation. ${ }^{4}$ In the same year, 1965, a collaborative effort between the IBM Corporation and the National Cancer 